\title{
A dynamic model to predict fat and protein fluxes and dry matter intake associated with body reserve changes in cattle
}

\author{
Luis O. Tedeschi, ${ }^{* 1}$ Danny G. Fox, $†$ and Paul J. Kononoff \\ *Department of Animal Science, Texas A\&M University, College Station 7743-2471 \\ †Department of Animal Science, Cornell University, Ithaca, NY 14853 \\ ‡Department of Animal Science, University of Nebraska-Lincoln, Lincoln 68583
}

\begin{abstract}
The objective of this paper was to develop the structure and concepts of a dynamic model to simulate dry matter intake (DMI) pattern and the fluxes of fat and protein in the body reserves of cattle associated with changes in body condition score (BCS) for application within the structure of applied nutrition models. This model was developed to add the capability of evaluating the effects of factors affecting pre- and postcalving DMI, daily energy and protein balances, and changes in BCS over a reproductive cycle. Input variables are average DMI, diet metabolizable energy, and animal information (body weight, BCS, milk production, and calf birth body weight) from each diet fed over the reproductive cycle. Because the depletion and repletion of body reserves in cattle is a complex system of coordinated metabolic processes that reflect hormonal and physiological changes caused by negative or positive energy balances, the system dynamics modeling methodology was used to develop this model. The model was used to evaluate the effect of the dynamic interactions between dietary supply and animal requirements for energy and protein on the fluxes of body fat and body protein of dairy cows over the reproductive cycle and Monte Carlo simulations were used to assess the sensitivity of the parameters. The main long-term factor affecting DMI pattern was the growth of the gravid uterus causing an increase in the volume of abdominal organs and a compression of the rumen, consequentially reducing feed intake. Changes in body reserves (fat and protein) were computed based on metabolizable energy balance, assuming different efficiency of utilization coefficients for fat and protein during repletion and mobilization. The model was evaluated with data from 37 dairy cows individually fed 3 different diets over the lactation and
\end{abstract}

Received August 20, 2012.

Accepted January 3, 2013.

${ }^{1}$ Corresponding author: luis.tedeschi@tamu.edu dry periods. The model was successful in simulating the observed pattern of DMI (mean square error was 3.59, 3.97, and 3.66 for diets A, B, and C, respectively), but it tended to underpredict DMI during late lactation [around 200 to $285 \mathrm{~d}$ in milk (DIM)] for all diets, suggesting changes in the model structure might be needed. The predicted BCS pattern had a trend similar to the observed values. Assuming that observed BCS represents actual body fat, the model tended to overpredict observed BCS during early lactation $(0.125$ BCS for 0 to 120 DIM) and underpredict it during late lactation (0.06 BCS for 180 to 270 DIM). A long-term simulation (5 lactations and 4 dry periods) with $\operatorname{diet} \mathrm{A}$ indicated that the cows on this diet would have a net loss of body fat if all conditions were constant.

Key words: dry matter intake, modeling, simulation, dynamic

\section{INTRODUCTION}

The depletion and repletion of body reserves in beef and dairy cattle is a coordinated metabolic process that reflects hormonal and physiological changes (Vernon and Houseknecht, 2000) caused by alternating negative or positive energy balances. A negative energy balance is the result of energy requirements exceeding the animal's ability to consume enough feed energy to meet energy requirements due to physiological limits or a decrease in feed energy supply (e.g., feed quality or quantity; Reed et al., 1997; Weder et al., 1999). Conversely, a positive energy balance is observed when the consumption of energy is greater than the amount required by the animal.

The body reserves of fat and protein as indicated by BCS $\left(\mathbf{B C S}_{1-9}\right.$ scale for beef cattle or $\mathrm{BCS}_{1-5}$ scale for dairy cattle) affect both milk production and reproduction of cows. It has been shown that overall efficiency of milk production and, therefore, production efficiency, is strongly correlated with changes in the metabolism due to physiological stage, including delayed body tissue mobilization in late lactation (Schwager-Suter et 
al., 2001). Morrison et al. (1999) studied the effects of BCS at prepartum on reproduction in multiparous beef cows and concluded that $\mathrm{BCS}_{1-9}$ lower than 5 affected the reproductive performance based on mean pregnancy rate and mean time to conception. Buskirk et al. (1992) reported that restricted feed intake tended to limit luteal activity by the end of the breeding season in beef cows and those with $\mathrm{BCS}_{1-9}$ less than 4 had a lower cycling rate at the end of the breeding season than those with good $\mathrm{BCS}_{1-9}(>4)$. Similar findings were reported by Houghton et al. (1990a). Blanc and Agabriel (2008) developed a model to study factors affecting the reproductive efficiency of beef cows and concluded that BCS at calving was a highly important factor. A systematic basis for predicting energy requirements for management groups of beef and dairy cows requires accounting for interdependent periods of negative and positive energy balance during a calving interval (Reyes et al., 1981; Williams et al., 1989). Accounting for body tissue energy fluxes in formulating diets can improve animal and economic performance over time by allowing animals to reach their genetic potential for milk yield, avoiding delayed conception and extended calving interval, and low body weight of calves at weaning (Canfield and Butler, 1991; ReynosoCampos et al., 2004).

Therefore, it is necessary to account for fluxes of body reserves to accurately predict energy and protein requirements of cows in an efficient production system. Dynamic models to simulate the adipose tissue metabolism in the ruminant animal have been discussed (Baldwin, 1995; McNamara, 2000; McNamara and Baldwin, 2000), but the level of information needed by these biochemical-based models may limit their application in the field. Applied nutrition models that account for changes in energy and protein reserves at a more aggregated level may suffice the needs for ration formulation and balancing purposes. Empirical equations developed to estimate energy content from BW, carcass soft tissue and composition, and BCS (Houghton et al., 1990b; Otto et al., 1991) are used to predict energy reserves pool size (NRC, 2000; Fox et al., 2004; Tedeschi et al., 2006). However, current applied nutrition models do not account for the effect of rations formulated for each stage of the reproductive cycle on the dynamic behavior of body reserves throughout the reproductive cycle. The objective of this study was to develop a dynamic reserves model that can be used within the structure of applied nutrition models (e.g., the Cornell Net Carbohydrate and Protein System-based models; Fox et al., 2004) to simulate DMI pattern, the fluxes of fat and protein of the body reserves, and changes in BCS of cattle associated with ME balances for each diet fed during the reproductive cycle.

\section{MATERIALS AND METHODS}

\section{Modeling Methodology}

The dynamic reserves model (DRM) was developed based on concepts described by Tedeschi et al. (2006) and the modeling process was based on system dynamics methodology (Sterman, 2000; Abdel-Hamid, 2002). The system dynamics methodology was developed to facilitate the understanding of complex systems and their dynamic behavior and complexity within the boundaries of the problem (Forrester, 1961). In system dynamics, self-reinforcing and self-correcting (balancing) loops are represented by positive and negative signs within the semicircle arrow in which reinforcing loops tend to amplify, whereas self-correcting loops counteract and oppose changes. In Figure 1, the positive and negative signs at the arrowheads indicate whether the effect is positively or negatively related to the cause. The fluctuations of BCS are intrinsically connected with the oscillations in supply (DMI and body reserves) and requirement for energy within a meticulously coordinated system using feedback signals. System dynamics and mathematical modeling can be used to describe these concepts and behaviors throughout the reproductive cycle. For model simulation purposes, the reproductive cycle (and calving interval) was assumed to be $365 \mathrm{~d}$ long, starting at conception (d 0).

\section{Model Development}

The DRM was developed using the graphical development and simulation environment of Vensim Decision Support System (DSS) for Windows version 5.9 (Ventana Systems Inc., Harvard, MA). The Euler integration technique was used with a time step of 0.0625 d. The payoff-based optimization in Vensim was used to estimate model parameters.

Modeling the Pattern of DMI Over the Reproductive Cycle. Substantial improvements in animal production can be achieved if energy and other nutrients are supplied according to the genetic potential of the animal. Nonetheless, in many situations, the DMI of feed may be below the desired target to maximize production (Forbes, 1993). The voluntary intake of feed DM is not fully understood because it is controlled by many complex and interacting signals, including shortand long-term diet, animal, and environmental factors. Short-term factors are likely responsible for the daily and weekly oscillatory behavior of the intake, whereas long-term factors are more likely to affect changes in voluntary DMI during the reproductive cycle.

The effects of short-term factors on DMI are derived mainly from characteristics of the diet [e.g., rates of 


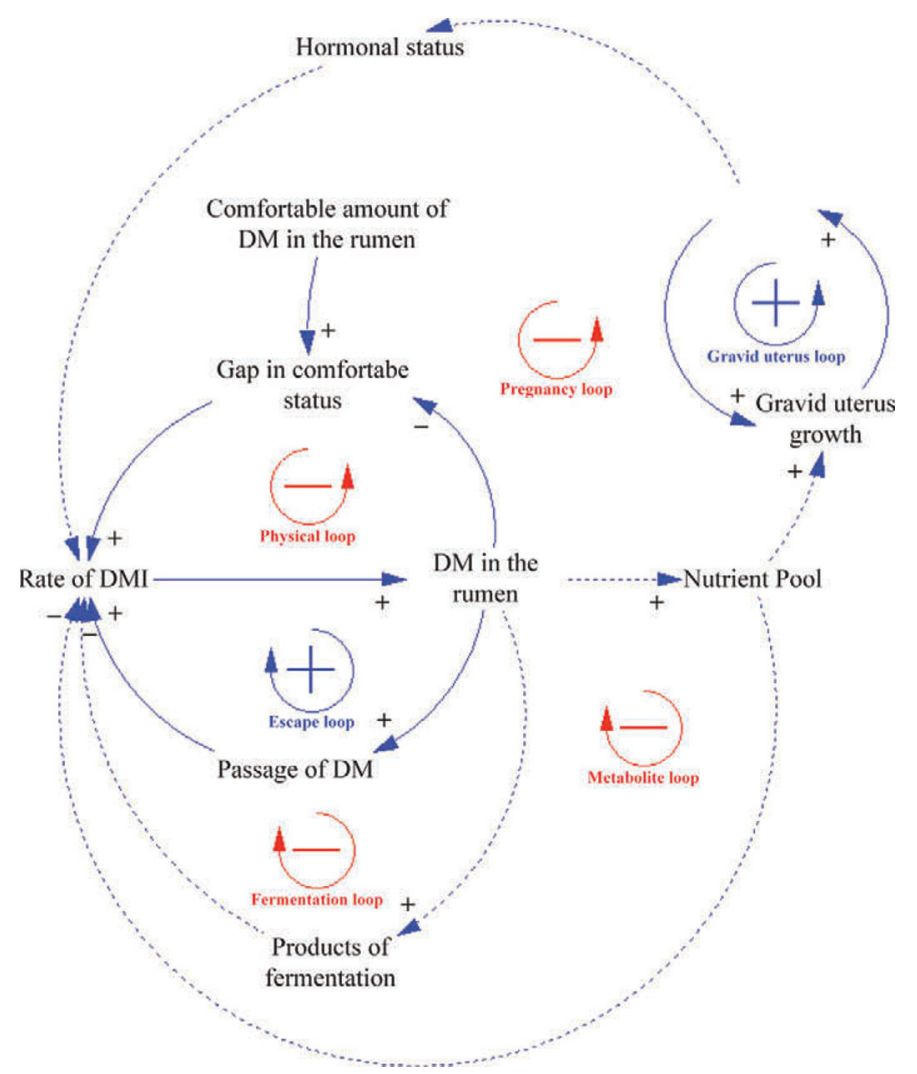

Figure 1. Conceptual representation of long- and short-term feedback loops affecting the dynamics of DMI in a ruminant animal. Selfreinforcing and self-correcting loops are represented by positive and negative signs within the semicircle arrow, respectively. Positive and negative signs near the arrowheads indicate that the effect is positively or negatively related to the cause. Color version available in the online PDF.

fermentation and passage (Mertens, 2005) and chemical composition] and the effects of ruminal fermentation end products (Forbes, 1995b) such as propionate, acetate, and butyrate, and the supply of nutrients postruminally (e.g., FA, glucose, and AA) on the ruminant metabolism (Allen et al., 2005). Another factor that in part affects intake is the physical distension of the rumen (Mbanya et al., 1993; Forbes, 1995a); the degree of rumen fill is affected by the rate feed is degraded and escapes the rumen (Clark and Armentano, 1997). Most of the short-term factors are controlled by the lateral hypothalamus area of the central and peripheral nervous system (Baile and McLaughlin, 1987). Figure 1 depicts a simplified loop diagram of long- and short-term factors. The dashed lines represent causal relationships exogenous to the current version of our model.

In addition to BW and milk production, the main factor affecting DMI is the increase in the volume of abdominal organs [e.g., gravid uterus $(\mathbf{G} \mathbf{U})$ ] that causes a compression of the rumen and consequently reduces feed intake during late pregnancy. Although during late pregnancy the girth of the abdomen may increase, it does not increase enough to accommodate the growth of the GU (i.e., fluids, fetus, placenta, and other tissues; Forbes, 1995b). Thus, it follows that at this time intake is restricted. Along with the decrease in the internal volume, a tremendous change in hormonal patterns occurs (Bell, 1995) that also contributes to changes in intake behavior. Additionally, there is an increase in the passage rate of feed DM through the digestive tract during pregnancy; however, this change is not enough to prevent a reduction in DMI (Forbes, 1995b). The effect of GU growth and pregnancy hormonal changes on DMI is referred to as the pregnancy loop in Figure 1.

As shown in Figure 1, the GU and physical feedback loops represent the long-term factors affecting the accommodation of the rumen capacity to feed DM and the escape loop represents the short-term effect on daily intake to satisfy the dynamics of ruminal fermentation and absorption of nutrients. Two other loops (fermentation and metabolites) are represented for illustrative purposes but because they are short-term factors affecting the daily oscillatory behavior of feed DMI, they were not accounted for in the present model.

Modeling the Pregnancy Effect on DMI. Figure 2 depicts the pregnancy model (Equations 1 to 4 ). The ratio of GU weight to a standard GU (SGU) weight (Equation 1) was used to scale the comfortable level of feed DM in the rumen to pregnancy status in which 0 would have no physical effect on DMI. The SGU weight (Equation 2) was set to be $180 \%$ of calf birth weight (CBW), assuming that CBW is about $55 \%$ of the GU (wet) weight for beef (Ferrell et al., 1976) and dairy (Bell et al., 1995) cows. Prior et al. (1979) observed that restriction on energy intake by the dam has little effect on the development of the fetus, provided the dam is able to maintain a constant BW. Therefore, restricted energy intake was assumed to have no effect on CBW in this model. Equation 3 is the differential equation used to estimate GU weight, which has an initial value of $1 \mathrm{~kg}$ and uses a fractional rate of growth of the GU $\left(\mathbf{k}_{\mathrm{GUg}}, \mathrm{d}^{-1}\right)$ and an average number of days for uterus involution (Di, $7 \mathrm{~d}$ ):

$$
\begin{gathered}
\mathrm{GUR}_{t}=\frac{\mathrm{GU}_{t}}{\mathrm{SGU}} \\
\mathrm{SGU} \text { weight }=1.8 \times \mathrm{CBW} ; \\
\frac{\mathrm{dGU}}{\mathrm{d} t}=\mathrm{k}_{\mathrm{GUg}} \times \mathrm{GU}_{t}-\frac{\mathrm{GU}_{t}}{\mathrm{Di}} \\
\mathrm{k}_{\mathrm{GUg}}=(\mathrm{CBW}-40) \times 0.0001+0.015
\end{gathered}
$$






Figure 2. Graphical representation of stock or state variables (box) and flows or rates variables (double line) of the gravid uterus development. Positive and negative signs at the arrowheads indicate that the effect is positively or negatively related to the cause. Color version available in the online PDF.

where GUR is the GU ratio, $t$ is time (d), and GU, SGU, and CBW are in kilograms. The SGU is $180 \%$ of a $40-\mathrm{kg}$ CBW.

The $\mathrm{k}_{\mathrm{GUg}}$ (Equation 4) is a function of CBW. It was assumed to be $1.5 \% / \mathrm{d}$ for a $40-\mathrm{kg} \mathrm{CBW}$ and it would change by $0.01 \% / \mathrm{d}$ per change in CBW from $40 \mathrm{~kg}$. In our model, the $\mathrm{k}_{\mathrm{GUg}}$ is intrinsically linear to the $\mathrm{GU}$; that means, the growth rate of the GU is linearly related to the GU. Evidence exists that this linearity may not hold true for all cases, as shown in the study of Ferrell et al. (1976) in which the growth rate had a nonlinear, downward parabolic relationship with GU. The linear $\mathrm{k}_{\mathrm{GUg}}$, as used in our model, would tend to overestimate $\mathrm{GU}$ toward the end of the pregnancy period compared with a downward parabolic $\mathrm{k}_{\mathrm{GUg}}$.

The GU weight is used to adjust BW to compute $\mathrm{ME}$ requirements for cow maintenance with the Large Ruminant Nutrition System (LRNS, College Station, TX; http://nutritionmodels.tamu.edu/lrns.html) model, which is based on the Cornell Net Carbohydrate and Protein System model version 5.0 as described by Fox et al. (2004).

Modeling the Physical Effect on DMI. Figure 3 depicts the long-term DM dynamics in the rumen for our model. The gastrointestinal or rumen distension due to fill or permanent displacement in the abdomen due to pregnancy is thought to cause a discomfort to the animal (Van Soest, 1994). Therefore, for pregnant animals, the comfortable amount of feed DM in the rumen (CDMR; Equation 5) is a function of GUR and the normal comfortable amount of feed DM in the rumen (NCDMR; Equation 6), which is initially assumed to be $1.6 \%$ of BW:

$$
\begin{gathered}
\mathrm{CDMR}_{t}=\left(1-\mathrm{GUR}_{t}\right) \times \mathrm{NCDMR}_{t} ; \\
\mathrm{NCDMR}_{t}=0.016 \times \mathrm{BW}_{t},
\end{gathered}
$$

where CDMR $(\mathrm{kg})$ has no physical effect restriction on DMI and NCDMR is in kilograms.

These values were obtained by simulating various scenarios with the LRNS equations (Fox et al., 2004). Additionally, assuming that rumen DM content is $13.3 \%$ of rumen contents (Alexander et al., 1969) and that rumen contents of a lactating cow (BW of $650 \mathrm{~kg}$ ) varies from 77 to $61 \mathrm{~kg}$ for normal and low-roughage levels (Sutton et al., 2003), the NCDMR varies from 1.3 to $1.6 \%$ of BW.

Equation 7 shows the differential equation to compute the DM in the rumen (DMR, $\mathrm{kg}$ ), which has an initial value identical to $\mathrm{NCDMR}_{t=0}$. The DMI rate (DMIR, kg/d; Equation 8) is computed based on the current amount of DMR, CDMR, and time to reach a comfortable level of DM in the rumen $(\mathbf{D c}, \mathrm{d})$ :

$$
\begin{gathered}
\frac{\mathrm{dDMR}}{\mathrm{d} t}=\mathrm{DMIR}_{t}-\mathrm{DMDR}_{t} \\
\mathrm{DMIR}_{t}=\left(\frac{\mathrm{CDMR}_{t}-\mathrm{DMR}_{t}}{\mathrm{Dc}_{t}}\right)+\mathrm{DMDR}_{t} .
\end{gathered}
$$

Two values for Dc were initially assumed: 110 and $25 \mathrm{~d}$ for before and after calving, respectively, which indicate a slower and faster accommodation to physiological stages. This assumption is supported by the observations of Gibb et al. (1992), who reported that during the early lactation period the small intestine increases in length and liver weight increases $31 \%$ to accommodate the increase in demand for energy and nutrients, therefore increasing the ability of the lactating animal to consume more feed.

The DM disappearance rate (DMDR, $\mathrm{kg} / \mathrm{d}$ ) is computed based on the average DMI (ADMI, kg/d) between 90 and 250 DIM, NCDMR, and DMR, as shown in Equation 9:

$$
\mathrm{DMDR}_{t}=\mathrm{DMR}_{t} \times\left(\frac{\mathrm{ADMI}}{\mathrm{NCDMR}_{t}}\right) .
$$

The DMDR is added to the DMIR to account for shortterm factors affecting DMI and, therefore, offsetting within-day or -week oscillations.

Further adjustments for the ADMI may include feeding management and milking times (DeVries et al., 2003), diet composition, and climatic changes (NRC, 2000, 2001). Thus, the use of different ADMI within a reproductive cycle may account for more variation in predicting observed DMI. When ADMI is not available, empirical equations (NRC, 2000, 2001; Fox et al., 2004) can be used to estimate ADMI. 


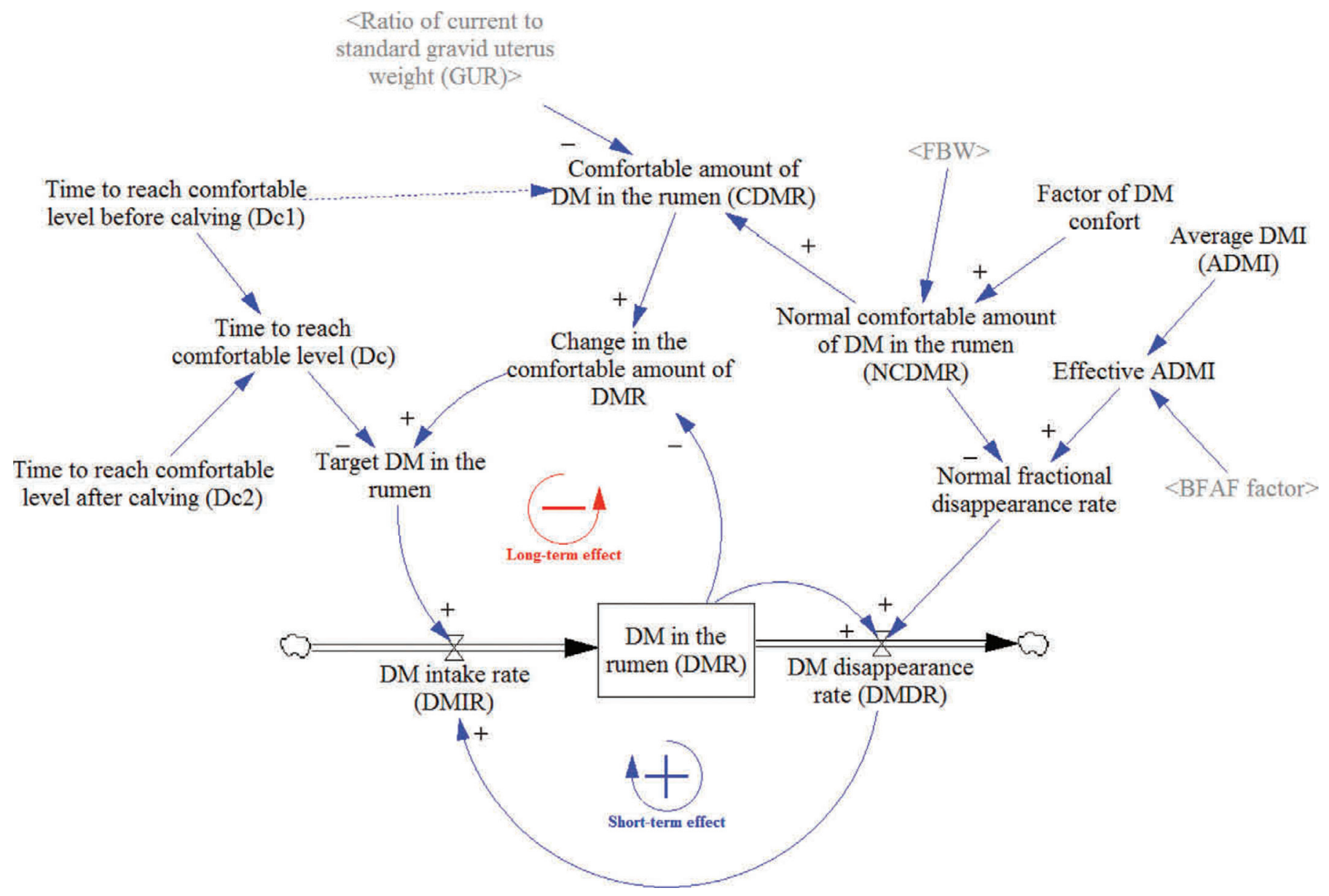

Figure 3. Graphical representation of stock or state variables (box) and flows or rates variables (double line) of the DM dynamics in the rumen. Variables within angle brackets were defined in another view of the model. Self-reinforcing and self-correcting loops are represented by positive and negative signs within the semicircle arrow, respectively. Positive and negative signs at the arrowheads indicate that the effect is positively or negatively related to the cause; FBW is full BW and BFAF is back fat adjustment factor on average DMI. Color version available in the online PDF.

Two options in calculating CDMR were included in the model. The first option is as described above: CDMR is adjusted continuously to GUR, as shown in Equation 5. The second option included a conditional calculation of CDMR in which CDMR would be equal to NCDMR until Dc days before calving (Equation 10). In other words, the adjustment of DMR to GU would only begin Dc days before calving. Unless stated, the first option to compute CDMR (Equation 5) was used.

$$
\mathrm{CDMR}_{t}=\left\{\begin{array}{c}
\mathrm{NCDMR}_{t} ; \text { if } t \geq \mathrm{PL}-\mathrm{Dc} \\
\left(1-\mathrm{GUR}_{t}\right) \times \mathrm{NCDMR}_{t} ; \text { if } t<\mathrm{PL}-\mathrm{Dc}
\end{array}\right.
$$

where CDMR (kg) has no physical effect restriction on DMI, NCDMR is in kilograms, PL is pregnancy length (assumed to be $280 \mathrm{~d}$ ), and Dc is the time to reach comfortable level of DM in the rumen before calving.

\section{Modeling the Fluxes of Fat and Protein Associated with BCS Changes}

The supply of ME and MP from feed digestion is exogenous to our model and can be obtained with applied nutrition models (e.g., LRNS), which are based on nutrient composition of the ingredients. The requirement for ME and MP is computed by this model. The requirements for maintenance and pregnancy are based on those of the LRNS (Fox et al., 2004). No adjustment for environment is made in predicting ME required for maintenance and DMI. Prediction of milk yield (MY) is with a modified version of the gamma function proposed by Wood (1967), as shown in Equation 11:

$$
\mathrm{MY}=a \times \mathrm{DIM}^{b} \times e^{-c \times \mathrm{DIM}} \times e^{-d \times \mathrm{DP}},
$$

where MY is in kilograms per day; $a, b, c$, and $d$ are parameters of the equation; and DP is days pregnant. 


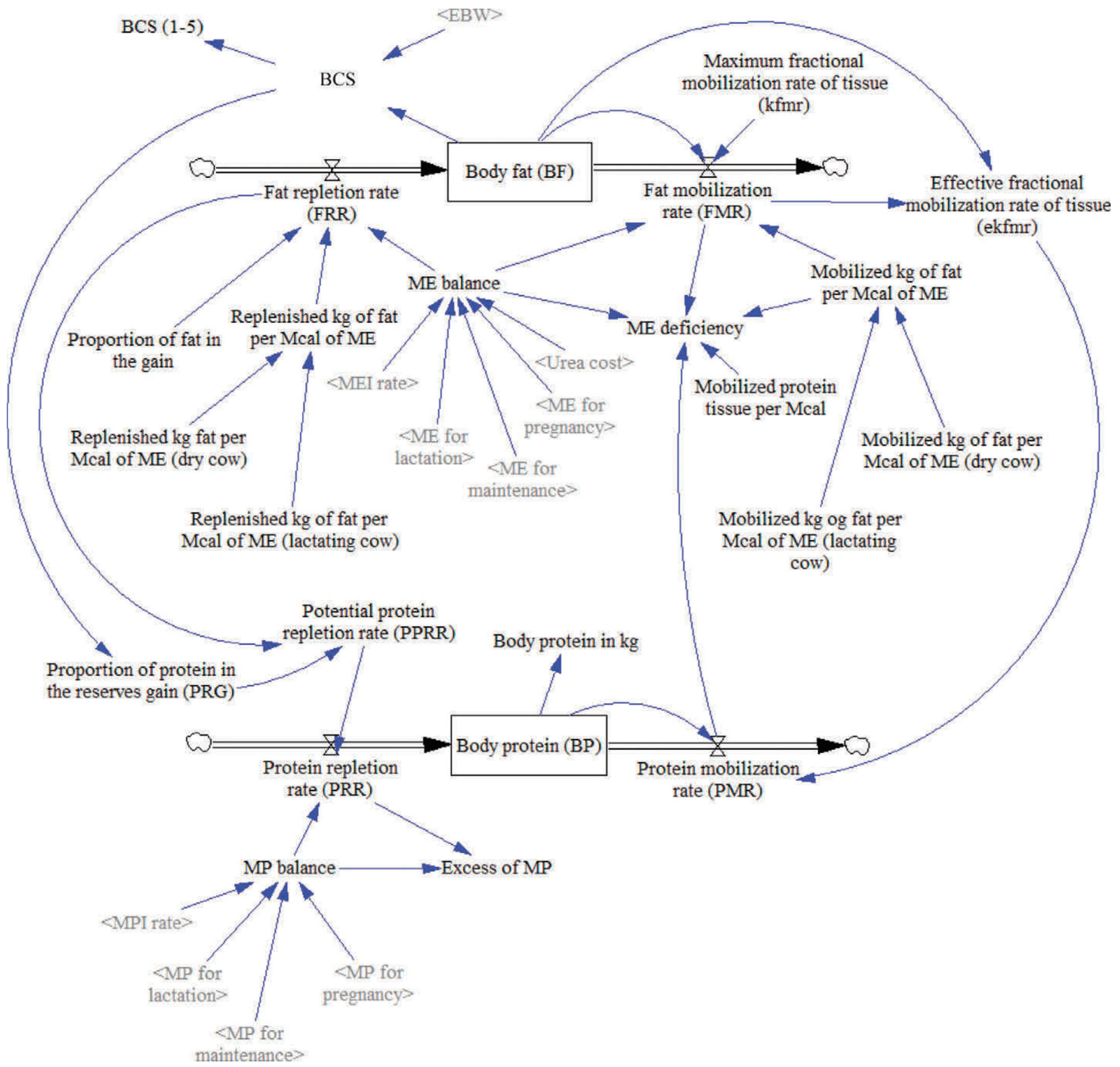

Figure 4. Graphical representation of stock or state variables (box) and flows or rates variables (double line) of body fat and protein dynamics. $\mathrm{EBW}=$ empty $\mathrm{BW}$; MEI = ME intake. Color version available in the online PDF.

In this model, tissue mobilization or repletion is dictated by the ME balance $(\Delta \mathrm{ME})$, which is the difference between ME supply and requirement. Figure 4 depicts the diagram (stock and flows) of the model of fluxes of fat and protein associated with BCS changes.

The initial body composition of fat and protein is calculated based on initial BCS and empty BW using the equations described by Tedeschi et al. (2006), which are based on those recommended by the NRC (2000).

Equations 12 to 14 are the calculations for repletion and mobilization of body fat (BF), as shown in the upper part of Figure 4:

$$
\frac{\mathrm{dBF}}{\mathrm{d} t}=\mathrm{FRR}-\mathrm{FMR}
$$




$$
\begin{gathered}
\mathrm{FRR}=\left\{\begin{array}{l}
0 ; \text { if } \Delta \mathrm{ME} \leq 0 \\
0.08 \times \Delta \mathrm{ME} ; \Delta \mathrm{ME}>0
\end{array} ;\right. \\
\mathrm{FMR}=\left\{\begin{array}{l}
\operatorname{Min}\left(\mathrm{k}_{\mathrm{fmr}} \times \mathrm{BF},-\Delta \mathrm{ME} \times 0.127\right) ; \text { if } \Delta \mathrm{ME}<0 \\
0 ; \text { if } \Delta \mathrm{ME} \geq 0
\end{array}\right.
\end{gathered}
$$

where BF is in kilograms, FRR is fat repletion rate $(\mathrm{kg} / \mathrm{d}), \mathbf{F M R}$ is fat mobilization rate $(\mathrm{kg} / \mathrm{d}), \Delta \mathrm{ME}$ is in megacalories per day, and $\mathbf{k}_{\mathrm{fmr}}$ is maximum fractional fat mobilization rate $(1 / \mathrm{d})$.

The FRR and FMR are dictated by $\triangle \mathrm{ME}$ balance. When $\triangle \mathrm{ME}$ balance is positive, the excess of energy is deposited at $0.08 \mathrm{~kg}$ of fat/Mcal of ME, which is the inverse of the net energy of fat (9.367) multiplied by its average efficiency of deposition (75\%) (Tedeschi et al., 2004).

Conversely, when $\triangle \mathrm{ME}$ balance is negative, the deficit of energy is assumed to result in a mobilization of tissue reserves. Komaragiri and Erdman (1997) indicated that $1 \mathrm{U}$ of change in BCS (1 to 5 scale) corresponded to $40 \mathrm{~kg}$ of BF. Similarly, Andrew et al. (1994) indicated that cows lost, on average, $42.4 \mathrm{~kg}$ of $\mathrm{BF}$ (89.9 to 47.5 $\mathrm{kg}$ ) from $7 \mathrm{~d}$ before calving to 62.9 DIM (average BW of 584 and $555 \mathrm{~kg}$, respectively). This is about 0.6066 $\mathrm{kg}$ of $\mathrm{BF}$ per day, which is approximately $0.0088 \mathrm{~d}^{-1}$, assuming an average BF during this period of 68.7 $\mathrm{kg}$. Those authors further indicated that $\mathrm{BF}$ was 18.8 and $10.7 \%$ of empty BW, respectively. Based on their study, we assumed a $\mathrm{k}_{\mathrm{fmr}}$ of $0.01 \mathrm{~d}^{-1}$ during lactation. This value is likely dependent upon breed and level of nutrition but more information is needed before these 2 effects can be accounted for. Higher values may also be found for other mammalian species (Bauman, 2000). If the $\mathrm{k}_{\mathrm{fmr}}$ is greater than the amount of energy needed to support maintenance and production, then only the amount of energy necessary is mobilized from the body reserve of fat. Therefore, FMR is the lowest value between that allowed by the $\mathrm{k}_{\mathrm{fmr}}$ or $0.127 \mathrm{~kg}$ of fat/ Mcal of ME, which is the inverse of the net energy of mobilized fat (7.868 Mcal of ME/kg). The 7.868 Mcal of $\mathrm{ME} / \mathrm{kg}$ is the net energy of fat (9.367) times its average utilization efficiency when mobilized from adipose tissue (84\%; Tedeschi et al., 2006). In this way, the first limiting of either that physiologically allowed $\left(\mathrm{k}_{\mathrm{fmr}} \times\right.$ $\mathrm{BF})$ or the amount needed $(-\Delta \mathrm{ME} \times 0.127)$ occurs. If the physiologically allowed amount is the first limited, then the cow will remain in negative energy balance.

The proportion of fat and protein in the empty body tissue, and the fat and protein in the gain or loss of body tissue can be predicted from BCS (NRC, 2000, 2001). Changes in BF and body protein are inversely related as BCS changes (NRC, 2000). Equations 15 to 20 summarize the calculation of fluxes of body protein (BP; Equation 15) as depicted in the lower part of Figure 4:

$$
\begin{gathered}
\frac{\mathrm{dBP}}{\mathrm{d} t}=\mathrm{PRR}-\mathrm{PMR} ; \\
\mathrm{PRR}=\left\{\begin{array}{l}
0 ; \text { if MP balance }(\Delta \mathrm{MP}) \leq 0 \\
\mathrm{Min}(\Delta \mathrm{MP}, \mathrm{PPRR}) ; \text { if } \mathrm{MP} \text { balance }>0
\end{array}\right. \\
\mathrm{PPRR}=\frac{1,000 \times \mathrm{FRR} \times \mathrm{PRG}}{1-\mathrm{PRG}} ; \\
\mathrm{PRG}=\frac{7.87374}{6.47877+\mathrm{BCS}_{1-9}}-0.215314 ; \\
\mathrm{PMR}=\mathrm{BP} \times \mathrm{ek}_{\mathrm{fmr}} \\
\mathrm{ek}_{\mathrm{fmr}}=\frac{\mathrm{FMR}}{\mathrm{BF}}
\end{gathered}
$$

where BP is in grams, $\mathbf{P R R}$ is protein repletion rate (g/d), PMR is protein mobilization rate $(\mathrm{g} / \mathrm{d}), \Delta \mathrm{MP}$ is in grams per day, PPRR is potential PRR $(\mathrm{g} / \mathrm{d})$, FRR is in grams per day, PRG is the proportion of protein in the reserve gain, BCS is on a scale from 1 to 9 , $\mathrm{ek}_{\mathrm{fmr}}$ is effective fractional fat mobilization rate $(1 / \mathrm{d})$, FMR is in kilograms per day, and BF is in kilograms.

Because they are inversely related, the repletion and mobilization of protein from body reserves is tightly connected to the fluxes of fat from body reserves. The PRR (Equation 16) depends on the FRR (Equation 13). The PPRR (Equation 17) is computed based on the FRR and the estimate of the PRG (Equation 18) based on BCS. The calculation of PPRR assumes that the ratio of fat to protein is maintained the same based on the BCS of the cow, using the equation adopted by the NRC (2000). The PMR (Equation 19) is also based on the FMR (Equation 14). An $\mathrm{ek}_{\mathrm{fmr}}$ is calculated from FMR and BF; this value is then multiplied by $\mathrm{BP}$ to compute PMR.

\section{Description of the Database Used to Evaluate the Model}

Individual cow data from the work reported by Kononoff et al. (2006) were used in the evaluation of our model, because it contained all of the inputs and outputs needed to evaluate it over a calving interval. Briefly, multiparous and primiparous Holstein cows were assigned to 3 different feeding regimens: no wet 
Table 1. Standardized regression coefficients for selected input and output variables of the model ${ }^{1}$

\begin{tabular}{|c|c|c|c|c|c|c|c|c|c|c|}
\hline Variable $^{2}$ & Diet ME & ADMI & $\mathrm{iFBW}$ & $\mathrm{K}_{\mathrm{GUg}}$ & $\mathrm{PL}$ & ClvI & \multicolumn{4}{|c|}{ Lactation variable } \\
\hline NCDMR & 0.51 & 0.44 & 0.27 & - & - & 0.39 & -0.29 & -0.39 & 0.21 & - \\
\hline DMR & 0.45 & 0.40 & 0.33 & -0.33 & - & 0.37 & -0.25 & -0.35 & - & - \\
\hline DMIR & -0.27 & 0.74 & - & -0.41 & - & - & - & 0.22 & - & - \\
\hline MEmr & 0.35 & 0.48 & 0.29 & - & - & 0.41 & -0.31 & -0.42 & 0.23 & - \\
\hline$\Delta \mathrm{MP}$ & -0.34 & 0.41 & - & -0.26 & - & 0.45 & -0.25 & -0.30 & - & -0.46 \\
\hline $\mathrm{BF}$ & 0.54 & 0.47 & - & - & - & 0.43 & -0.30 & -0.40 & 0.21 & - \\
\hline
\end{tabular}

${ }^{1} \mathrm{ADMI}=$ average DMI $(\mathrm{kg} / \mathrm{d}) ; \mathrm{iFBW}=$ initial full $\mathrm{BW}(\mathrm{kg}) ; \mathrm{k}_{\mathrm{GUg}}=$ fractional rate of growth of gravid uterus $\left(\mathrm{d}^{-1}\right) ; \mathrm{PL}=$ pregnancy length $(\mathrm{d})$; ClvI = calving interval (d); ca, cb, and cc are parameters of the Wood (1967) equation to predict MY; milk TP = milk true protein (g).

${ }^{2} \mathrm{NCDMR}=$ normal comfortable amount of feed DM in the rumen $(\mathrm{kg}) ; \mathrm{CDMR}=$ comfortable DM in the rumen $(\mathrm{kg}) ; \mathrm{DMR}=\mathrm{DM}$ in the rumen $(\mathrm{kg}) ; \mathrm{DMIR}=\mathrm{DMI}$ rate $(\mathrm{kg} / \mathrm{d}) ; \mathrm{MEmr}=\mathrm{ME}$ required for maintenance $(\mathrm{Mcal} / \mathrm{d}) ; \mathrm{MPmr}=\mathrm{MP}$ required for maintenance $(\mathrm{g} / \mathrm{d}) ; \mathrm{MY}=\mathrm{milk}$ yield $(\mathrm{kg} / \mathrm{d}) ; \Delta \mathrm{ME}=\mathrm{ME}$ balance $(\mathrm{Mcal} / \mathrm{d}) ; \Delta \mathrm{MP}=\mathrm{MP}$ balance $(\mathrm{g} / \mathrm{d}) ; \mathrm{BF}=$ body fat $(\mathrm{kg})$.

corn gluten feed (diet A; control) or fed wet corn gluten feed during lactation only (diet B) or during lactation and dry periods (diet C). For all cows, DMI, BCS, BW, and MY were collected. Furthermore, cows were genotyped for leptin SNP (CC, CT, or TT) similar to the procedure described by Kononoff et al. (2005). Cows were selected based on completeness and contiguousness of the data needed to evaluate that section of the model. The ADMI was the maximum DMI between 90 and 115 DIM. The ME and MP balances for each cow were computed with the LRNS.

\section{Statistical Analyses}

The differential equations were converted to an algebraic form using Mathematica v. 8.0 (Wolfram Research, Champaign, IL). Discrete intervals of observed values (e.g., BW) were ignored in obtaining the nonlinear algebraic form; multiple independent integrations would be required to properly account for discrete data. Therefore, continuous algebraic equations were developed for before calving and after calving. The PROC NLIN of SAS (SAS Institute Inc., Cary, NC) was used to solve the nonlinear algebraic equations with the Marquardt method. Because of the importance of data points between 0 and 90 DIM and the fewer numbers of points compared with the rest of the lactation period, a weight of 10 was assigned to data points within this interval; all other points had weight of 1 . The PROC MIXED of SAS (SAS Institute Inc.) was used to identify the effect of diet and leptin genotype on model parameters and output variables (Table 1). To simplify the model and broaden its application, empirical equations to predict DMIR were tested and selected with TableCurve 2D v. 5.0.1 software (SYSTAT Software Inc., Chicago, IL) based on goodness of fit of simulated values generated by the DRM.

\section{Model Evaluation}

Model adequacy was carried out with the Model Evaluation System (MES, College Station, TX; http:// nutritionmodels.tamu.edu/mes.html) as described by Tedeschi (2006). Briefly, model adequacy was assessed for precision and accuracy, including residual analysis, coefficient of determination, concordance correlation coefficient, and model accuracy (Cb; Lin, 1989; King and Chinchilli, 2001; Liao, 2003), mean square error of prediction (MSEP) and its decompositions into mean bias, systematic bias, and random errors (Bibby and Toutenburg, 1977), and nonparametric analysis. Comparison between models were assessed using $\Delta$ Akaike information criterion statistics (Burnham and Anderson, 2002) and the pairwise MSEP analysis (Wallach and Goffinet, 1989) as discussed by Tedeschi (2006).

\section{Sensitivity Analyses}

Model Parameters. In this analysis, Equation 8 was fitted to observed DMI within the structure of the model (Equations 1 to 9 ). To simplify the model and to prevent overparameterization of the model, the values of the parameters NCDMR, $\mathrm{k}_{\mathrm{GUg}}$, and Dc obtained for each cow were regressed on other input variables (e.g., $\mathrm{BW}$ ) to verify their correlation. If a high correlation ( $\mathrm{r}$ $>0.7$ ) was observed for a parameter, then an equation was obtained for its prediction within the model structure and Equation 8 was refitted without that parameter (which is now being predicted from another input variable). This stepwise fitting and convergence was done until no parameter left in the nonlinear model had a significant correlation with another input variable. This approach ensured the calibration of the nonlinear model for each variable at a time. The identifiability of the model parameters (uniqueness) as discussed by 
Boston et al. (2007) and Tedeschi and Boston (2010) was not investigated.

Complete Model. We performed Monte Carlo simulations, a computational technique that relies on repeated random sampling of input variables, to assess concomitant effects of variables on the value and distribution of output variables. The values of the input variables are based on probability density functions from which samples are drawn to perform the desired calculations; we assumed normal distribution for input variables with a mean and standard deviation equivalent to $5 \%$ of the mean. The Monte Carlo simulation was performed with @Risk v. 6.0 (Palisade Corp., Ithaca, NY) using 5,000 iterations and Latin hypercube sampling. Standardized regression coefficients (SRC; Kutner et al., 2005) were used to identify the most influential variables on the simulation output.

\section{RESULTS AND DISCUSSION}

\section{Sensitivity Analyses}

Predicting DMI. The NCDMR averaged $10.9 \pm 1.8$ $\mathrm{kg}$ and varied from 7.5 to $14.8 \mathrm{~kg}$. The regression between converged NCDMR and observed BW indicated that NCDMR was, on average, $1.819 \%$ of BW $(\mathrm{n}=29$; $\mathrm{r}^{2}=0.79$; root of mean square error $(\mathbf{M S E})=0.854$ $\mathrm{kg}$ ), suggesting that NCDMR could be computed from BW. This value was close to the $1.6 \%$ proposed initially (Equation 6). Then, in the next analysis, NCDMR was calculated from BW, removed from the parameter list, and the model was fitted with $\mathrm{k}_{\mathrm{GUg}}$, and Dc. In this analysis, $\mathrm{k}_{\mathrm{GUg}}$ was highly correlated with Dc before calving $(\mathrm{r}=0.87 ; \mathrm{n}=17)$ and varied from 0.0123 to $0.0204 \mathrm{~d}^{-1}$; our initial value of $0.015 \mathrm{~d}^{-1}$ is within this range. Therefore, in the subsequent analysis, Dc was allowed to converge and $\mathrm{k}_{\mathrm{GUg}}$ was computed using Equation 4 . The values of Dc before calving varied from 10.6 to $289 \mathrm{~d}$ (mean of $83 \mathrm{~d}$ ) and after calving they ranged from 2 to $121 \mathrm{~d}$ (mean $39 \mathrm{~d}$ ).

Alternatively, $\mathrm{k}_{\mathrm{GUg}}$ could be computed using Equation 21; assuming an SGU of $72 \mathrm{~kg}(40 \times 1.8$; Equation 2) and pregnancy length of $280 \mathrm{~d}, \mathrm{k}_{\mathrm{GUg}}$ is $0.0153 \mathrm{~d}^{-1}$, which is similar to the value assumed in Equation 4 when $\mathrm{CBW}$ is $40 \mathrm{~kg}$.

$$
\mathrm{k}_{\mathrm{GUg}}=\frac{\ln (\mathrm{SGU})}{\mathrm{PL}},
$$

where SGU is in kilograms, $\mathrm{k}_{\mathrm{GUg}}$ is in days ${ }^{-1}$, and PL is in days.

No correlation $(P>0.10)$ was observed between Dc before and after calving with measured data (DMI, MY, and BW), suggesting that Dc might be specific for each cow or may have external influences. In fact, an interaction $(P=0.09)$ between $\operatorname{diet}(\mathrm{A}, \mathrm{B}$, and $\mathrm{C})$ and leptin SNP was observed on the Dc before calving. When receiving diets A (control) and B (wet corn gluten feed during lactation only), the Dc value increased when a $\mathrm{T}$ allele was present $(\mathrm{CT})$ compared with the $\mathrm{CC}$ genotype and decreased when the TT genotype was present compared with the CT genotype. In contrast, when cows received diet $\mathrm{C}$ (wet corn gluten feed during lactation and dry periods) adding a $\mathrm{T}$ allele (CT) decreased the Dc value and a TT genotype cow increased Dc compared with the CT genotype. On average, an increase in the Dc value will increase DMI during precalving. Further work is needed to clearly understand this genotype and modeling parameter interaction on DMI of dairy cows.

Complete Model. Table 1 has the SRC for selected input and output variables of the model that had SRC greater than \pm 0.2 . The SRC reflects the change in the standard deviation of the dependent (output) variable associated with 1-U change in the standard deviation of the independent (input) variable at a ceteris paribus condition, specifically when all other input variables are fixed and unchanged. As expected, diet ME and ADMI had a greater influence on most output variables; the SRC ranged from 0.4 to 0.74 for ADMI and -0.27 to 0.51 for diet ME, suggesting that diet ME and ADMI (computed around 90 to 115 DIM) are important factors determining the predictions of the current model. Calving interval (days of reproductive cycle) also had an influential positive effect on $\triangle \mathrm{ME}, \Delta \mathrm{MP}$, and $\mathrm{BF}$, likely because $\Delta \mathrm{ME}, \Delta \mathrm{MP}$, and $\mathrm{BF}$ did not oscillate as much when the calving interval was short (about 365 d). This result may be viewed to interpret that cows will increase the calving interval to maintain a positive $\triangle \mathrm{ME}$ (or $\triangle \mathrm{MP}$ ) and (or) BF. The BCS is highly correlated with $\triangle \mathrm{ME}$ and BF. Pryce et al. (2000) indicated a moderate genetic correlation between BCS and calving interval and suggested that thinner cows (less $\mathrm{BF}$ and more often negative $\Delta \mathrm{ME}$ ) had longer calving intervals. They also reported high genetic correlations between calving interval and MY and milk composition (ranging from 0.56 to 0.61 ).

\section{Evaluation of Model Predictions}

Predicting DMI with the Dynamic Model. Figure $5 \mathrm{~A}$ depicts the relationship between the averages of predicted and observed DMI of individual cows $(\mathrm{n}=$ $37)$. On average, the model overpredicted by $0.58 \mathrm{~kg} / \mathrm{d}$ $(P=0.55)$ with a high accuracy $(\mathrm{Cb}$ of 0.98$)$ and high precision $\left(\mathrm{R}^{2}\right.$ of 0.96$)$. The root of MSEP (RMSEP) was $1 \mathrm{~kg} / \mathrm{d}$. When we evaluated all points $(\mathrm{n}=1,445)$, 



Figure 5. Relationship between the $(A)$ average $(n=37)$ and $(B)$ individual values $(n=1,445)$ of predicted versus observed DMI of individual cows $(\mathrm{n}=37)$. The solid line is the $\mathrm{Y}=\mathrm{X}$ line and the dashed line is the trend line.

even though the precision was reduced $\left(\mathrm{R}^{2}=0.71\right)$, the accuracy $(\mathrm{Cb}$ of 0.99$)$ and the magnitude of the mean bias $(-0.55 \mathrm{~kg} / \mathrm{d} ; P<0.001)$ were similar to the average. However, the RMSEP increased to 3.24 $\mathrm{kg} / \mathrm{d}$. Several complex mathematical models describing the effects of short-term (Forbes, 1980; Illius and Gordon, 1991; Poppi et al., 1994) and long-term (Petruzzi and Danfær, 2004; Petruzzi et al., 2004) factors on DMI have been developed. In general, there is a lack of comprehensive integration with physiological states of the animal (production and reproduction) or supply and requirement of energy and nutrients by the animal within a reproductive cycle.

Figure 6 illustrates the predicted and observed DMI for cows over the reproductive cycle receiving diets $\mathrm{A}$,
B, and C. Observed BW, BCS, and MY were used in this simulation. The estimated average DMIR was 22.3, 27.5 , and $25.8 \mathrm{~kg} / \mathrm{d}$; the Dc before calving was 136,77 , and $78 \mathrm{~d}$; the Dc after calving was 39,43 , and $44 \mathrm{~d}$; and diet ME was assumed fixed at 2.47, 2.31, and $2.45 \mathrm{Mcal} /$ $\mathrm{kg}$ for diets $\mathrm{A}, \mathrm{B}$, and $\mathrm{C}$, respectively. The MSE was $3.59,3.97$, and 3.66 for diets A, B, and C, respectively. For all diets, the model tended to underpredict DMIR at later lactation (around 200 to 285 DIM). First, lack of measured DMI near prepartum may have resulted in a bias in estimating Dc before calving. Second, the convergence of the model parameters was forced to assume a heavier statistical weight for postcalving DMI data to ensure that postparturition DMI was being properly represented. Despite the underprediction, the 

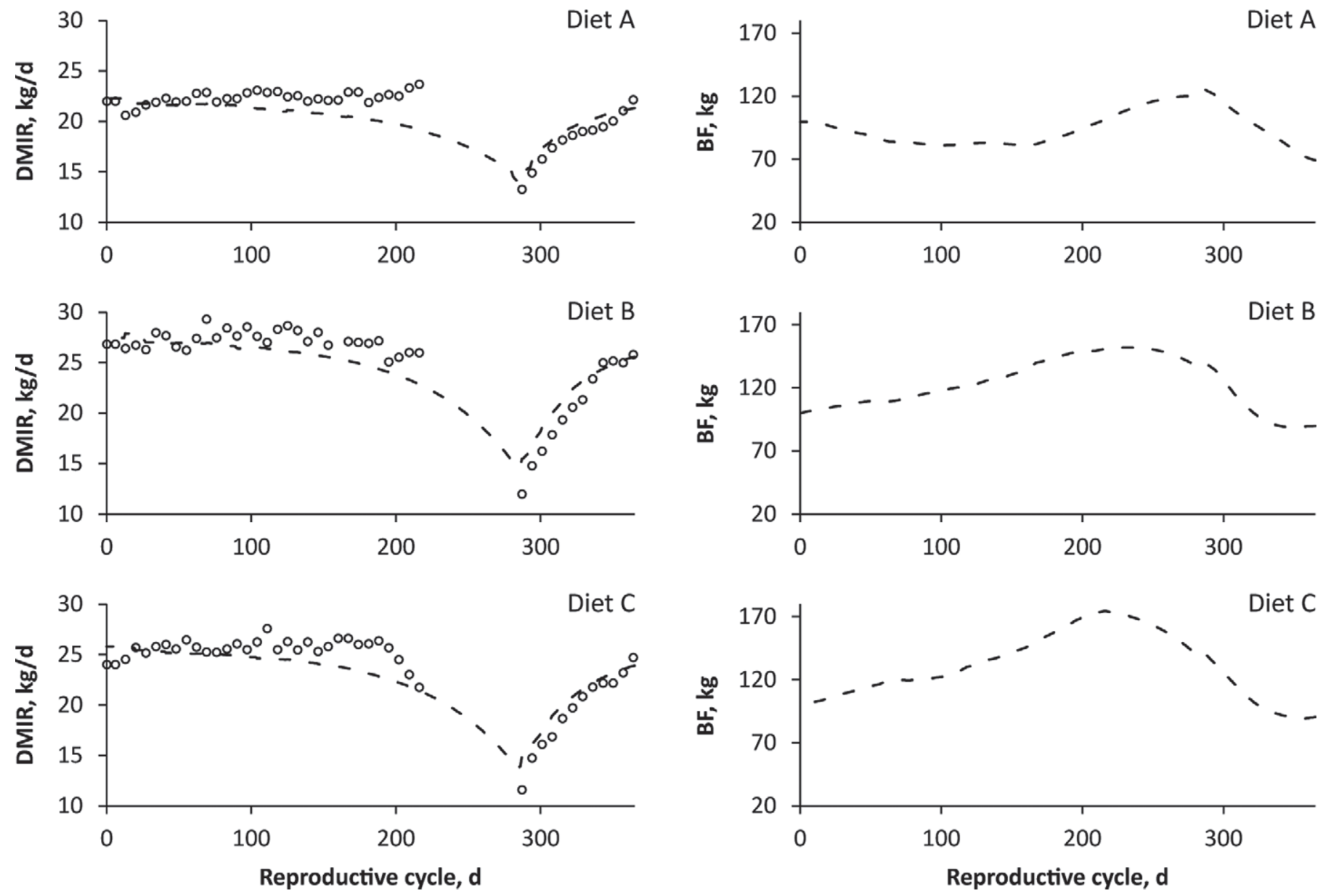

Figure 6. Predictions of DMI rate (DMIR; left panel) and body fat (BF; right panel) using the dynamic model and converged model parameters for diets $\mathrm{A}, \mathrm{B}$, and $\mathrm{C}$. The $\mathrm{BF}$ was predicted using the observed DMIR.

model was successful in simulating the pattern of DMI. The pattern of DMI was similar to that reported by Ingvartsen and Andersen (2000). According to those authors, DMI peaked between 8 and 22 wk after calving (56 to 154 DIM), which would occur around 0 to $65 \mathrm{~d}$ (reproductive cycle). This is in agreement with the predicted DMI for all diets.

When option 2 to compute CDMR (Equation 10) and the Vensim optimization were used, the Dc values for before calving were 59,31 , and $34 \mathrm{~d}$ and for after calving they were 25,31 , and $31 \mathrm{~d}$ for diets $\mathrm{A}, \mathrm{B}$, and $\mathrm{C}$, respectively. The MSE was lower compared with option $1(2.29,1.96$, and 2.38 for diets $\mathrm{A}, \mathrm{B}$, and $\mathrm{C}$, respectively) likely due to the better fit before calving. Although the models are different, the average adjustment time for DMI before calving reported by Hayirli et al. (2003; $6.5 \mathrm{~d}$ for dairy cows) is smaller than the one obtained with our model (31 to $59 \mathrm{~d})$. This suggests that option 2 for CDMR adjustment provides better estimates of DMI near the transition phase of dry to lactating cows. This also suggests that DMI may not decline until a month before calving and a steeper decline is expected. However, graphical analysis of the decline in DMI of our database suggests this is highly variable depending upon unidentified animal factors.

Short-term factors that affect DMI follow a dayto-day oscillatory pattern and control or regulate the satiety of the animal and are known as homeostatic control factors. Pregnancy and lactation (reproductive cycle) are long-term events that follow the homeorhetic theory, which involves a coordination of metabolism to ensure a uniform flow of nutrients in support of a physiological state (Bauman, 2000). As illustrated in Figure 6 , our dynamic model follows dynamic shifts in homeostatic signals that regulate intake over a reproductive cycle. Assuming the cow is not deprived of energy or other nutrients needed to reach their genetic production level, we assumed that homeostatic behavior (dayto-day variation in intake) has only temporary effects in determining animal performance in the long term. 


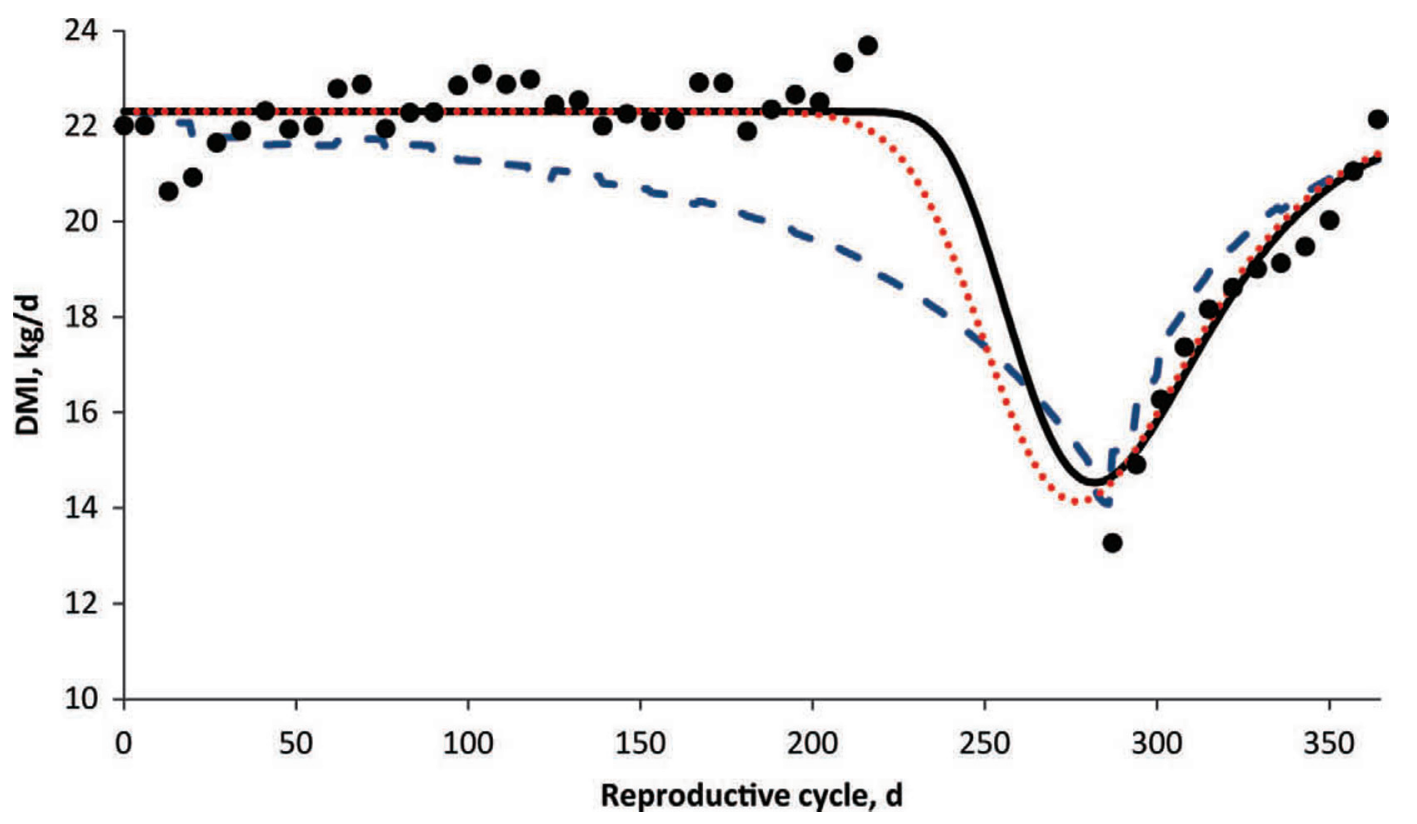

Figure 7. Comparison between of 2 empirical equations (logistic power peak, solid line; and asymmetric logistic peak, dotted line) and the dynamic model (dashed line) to predict DMI versus observed DMI $(\bullet)$ for cows fed diet A. Color version available in the online PDF.

An Empirical Equation to Predict DMI Pattern. Although the dynamic model, as shown in Equations 1 to 9 , predicted well the variation in DMI of dry and lactating cows during the reproductive cycle, a simple equation to predict DMI throughout the reproductive cycle could be more easily used in nutrition models. Two asymmetric nonlinear functions were able to fit the DMI pattern obtained by Equations 1 to 9 . The first candidate was the logistic power peak (LPP; Equation 22) and the second candidate was the asymmetric logistic peak (ALP; Equation 23) functions:

$$
\begin{aligned}
& \mathrm{DMIR}=a+\frac{b}{e}\left[1+\operatorname{Exp}\left(\frac{t+d \times \ln (e)-c}{d}\right)\right]^{\frac{-e-1}{e}} \times \\
& \operatorname{Exp}\left(\frac{t+d \times \ln (e)-c}{d}\right) \times(e+1)^{\frac{e+1}{e}} ; \\
& \mathrm{DMIR}=a+f\left[1+\operatorname{Exp}\left(-\frac{t+h \times \ln (d)-g}{h}\right)\right]^{(-i-1)} \times \\
& i^{-i}(i+1)^{i+1} \operatorname{Exp}\left(-\frac{t+h \times \ln (d)-g}{h}\right),
\end{aligned}
$$

where $a$ represents the average DMI; $b$ and $f$ represent the difference between $a$ and the DMI at calving; $c$ and $g$ represent the pregnancy length; $d, e, h$, and $i$ are coefficients used to shape the decrease and the increase of DMI before and after calving.

Figure 7 shows the prediction of DMIR using the LLP empirical model $(\mathrm{a}=22.3 \pm 0.12, \mathrm{~b}=-7.77 \pm$ $1.39, \mathrm{c}=281.79 \pm 11.9, \mathrm{~d}=-27.2 \pm 4.39$, and $\mathrm{e}=$ $1.67 \times 10^{-13} \pm 0.365$ ), the ALP empirical model ( $\mathrm{f}=$ $-8.17 \pm 1.57, \mathrm{~g}=277 \pm 13.2, \mathrm{~h}=26.58 \pm 6.17$, and $\mathrm{i}=4.75 \pm 9.69$ ), and the dynamic model (Equations 1 to 9), assuming Dc before and after calving of 134 and 38, respectively; ADMI of $22.3 \mathrm{~kg} / \mathrm{d}$; and $\mathrm{CBW}$ of $40 \mathrm{~kg}$. Both empirical functions had better adequacy statistics than Equations 1 to 9. For instance, for diet A, the coefficient of determination was $0.58,0.92$, and 0.93; the $\mathrm{Cb}$ was $0.848,0.994$, and 0.997 ; the RMSEP was $1.69,0.662$, and $0.634 \mathrm{~kg} / \mathrm{d}$ for Equations 1 to 9 , ALP, and LLP models, respectively. Although LPP and ALP were not different $[\Delta$ Akaike information criterion $=2.87(P=0.19)$ and pairwise $\mathrm{MSE}=-0.036(P$ $=0.26)]$, LPP had slightly better adequacy statistics than ALP, likely because ALP started decreasing predicted DMI earlier than the LPP function. A limitation of using empirical equations such as these is the interpretation of the parameters. It is likely that these empirical equations may be used with genetic/genomic information to characterize the parameters under different feeding conditions, but more information (e.g., genomics) is needed. In developing their DMI model for prefresh transition cows, Hayirli et al. (2003) reported that the parameters of the empirical equation were af- 

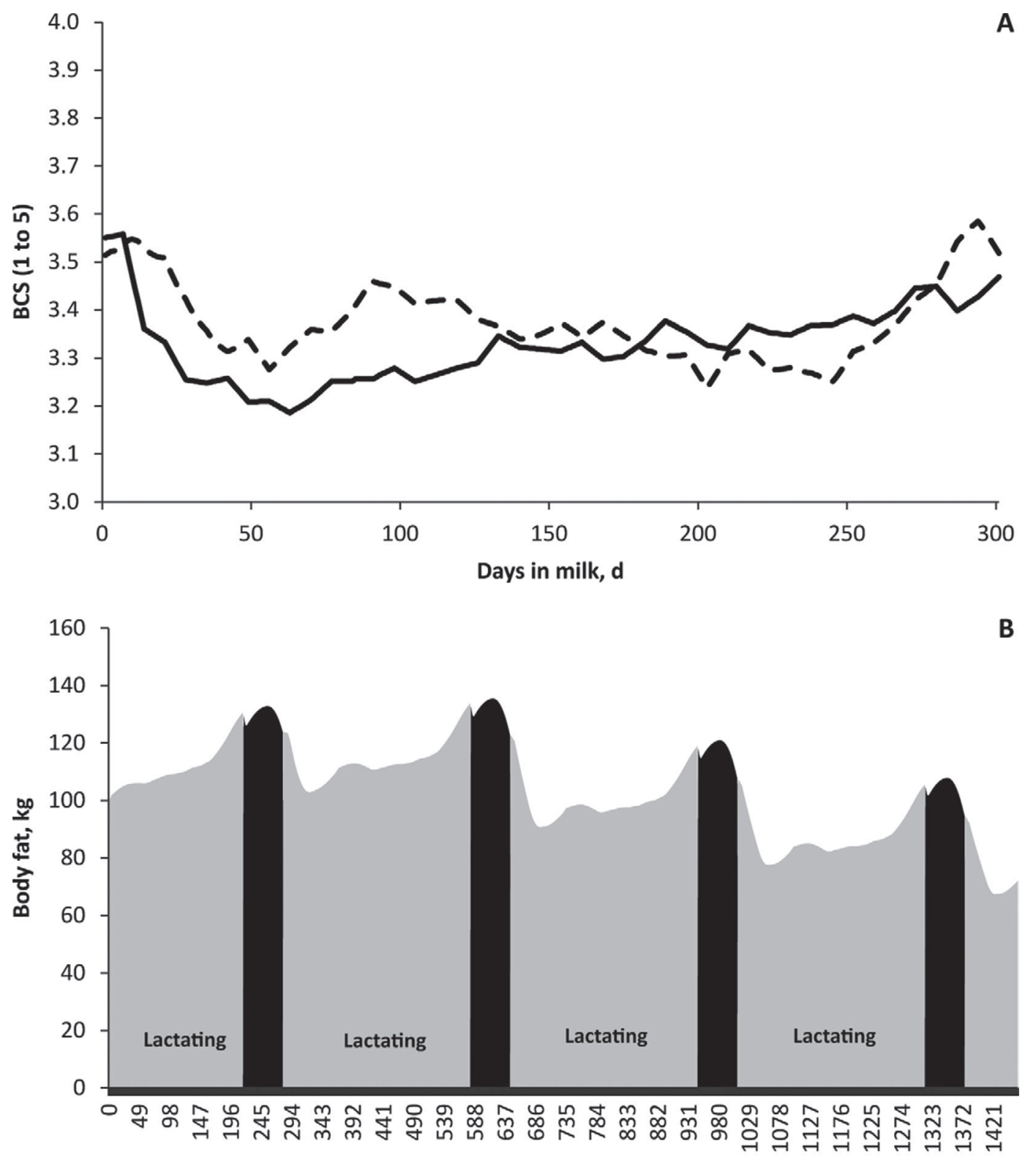

Simulation time, $d$

Figure 8. Relationship between (A) predicted (dashed line) versus observed BCS (solid line) and predicted fluctuation of body fat during 5 lactations (gray) intercalated with 4 dry (black) periods of cows fed diet A.

fected by BCS and dietary concentration of nutrients. In our model, predictions of DMI were not adjusted for cow BF or BCS.

Predicting Changes in Body Fat and Protein. Figure 6 also illustrates the predicted BF for cows consuming diets $\mathrm{A}, \mathrm{B}$, and $\mathrm{C}$. The simulated pattern of $\mathrm{BF}$ changes using Equations 12 to 20 suggested that BF accumulated before calving and decreased subsequent to calving (Figure 6). This trend was similar among the 3 diets, except that cows fed $\operatorname{diet} \mathrm{A}$ decreased $\mathrm{BF}$ between 100 and $200 \mathrm{~d}$ (185 to 285 DIM), likely due to the high milk fat content and low DMI. At $365 \mathrm{~d}$ (5 DIM), cows receiving diet $\mathrm{C}$ had more $\mathrm{BF}$ than those from diet A and B. Several factors can affect BF and $\mathrm{BP}$ at the same time. Consequently, we optimized key variables using the payoff-based optimization of Vensim to match the observed BCS of cows fed diet A.

The optimized variables and their values were diet ME for dry, 0 to 90 DIM, and 90 to 305 DIM (1.63, 2.79 , and $2.58 \mathrm{Mcal} / \mathrm{kg}$, respectively); Dc before and 
after calving was 58 and $20 \mathrm{~d}$, respectively; and the proportion of fat in the reserves gain was $92 \%$. The mobilization of reserves of fat per megacalorie of ME required was 0.107 during the dry period (likely for soon before calving) and 0.115 during lactation. Assuming a heat of combustion of fat of $9.367 \mathrm{Mcal} / \mathrm{kg}$, the efficiency of mobilization was $99 \%$ for dry and $92.8 \%$ for lactating periods, suggesting greater efficiency in fat mobilization during the dry period. These efficiencies are likely too high based on measured efficiency of reserves to milk production of $82.5 \%$ (Kirkland et al., 2002).

The optimization also indicated that each surplus Mcal of ME would replenish $0.055 \mathrm{~kg}$ of BF (0.515 Mcal of BF per Mcal of ME), yielding an efficiency of utilization of $52 \%$. The range of this coefficient is likely to be between 0.05 to $0.14 \mathrm{~kg}$ of $\mathrm{BF} /$ Mcal of ME based on the variation of the efficiency of deposition (Rattray et al., 1974; Rattray and Joyce, 1976).

The predicted BCS pattern (Figure 8A) had a trend similar to the observed values. The pattern is similar to that reported by Mao et al. (2004), but the model tended to overpredict BCS during early lactation $(0.125$ BCS for 0 to 120 DIM) and underpredict it during late lactation (0.06 BCS for 180 to 270 DIM). Measurement of BCS is subjective. Although BCS prediction was within acceptable limits, a long-term simulation indicated the cow would lose BF (Figure 8A) if all conditions were constant (ceteris paribus), except for time.

\section{CONCLUSIONS}

Several metabolic changes occur during the transition from late pregnancy to early lactation that can markedly affect the intake behavior of transition cows (Reynolds et al., 2003; Allen et al., 2009). Additionally, animal management and diet characteristics may also affect how cows respond to these changes in the transition period. Although the current model was able to simulate the pattern of DMI after calving, its ability to predict the pattern of DMI before calving was not consistent and needs to be improved (Figure 6). For instance, the model tended to decrease DMI earlier for $\operatorname{diets} \mathrm{A}$ and $\mathrm{B}$ compared with $\operatorname{diet} \mathrm{C}$, resulting in an overall underprediction. This suggests that the effect of the volume of abdominal organs on the reduction of feed intake during late pregnancy may need to be further relaxed in the current model and the CDMR adjustment may only commence Dc days before calving. Further modifications should include the effect of other factors such as diet characteristics (e.g., fiber) on the decline of precalving DMI as well as a more complete database containing DMI closer to the parturition for evaluation purposes.

\section{REFERENCES}

Abdel-Hamid, T. K. 2002. Modeling the dynamics of human energy regulation and its implications for obesity treatment. Syst. Dyn. Rev. 18:431-471.

Alexander, C. L., R. M. Meyer, and E. E. Bartley. 1969. Effect of quantity of rumen dry matter and other factors on determinations of rumen fluid volume with polyethylene glycol. J. Anim. Sci. 29:69-74.

Allen, M. S., B. J. Bradford, and K. J. Harvatine. 2005. The cow as a model to study food intake regulation. Annu. Rev. Nutr. 25:523-547.

Allen, M. S., B. J. Bradford, and M. Oba. 2009. Board-Invited Review: The hepatic oxidation theory of the control of feed intake and its application to ruminants. J. Anim. Sci. 87:3317-3334.

Andrew, S. M., D. R. Waldo, and R. A. Erdman. 1994. Direct analysis of body composition of dairy cows at three physiological stages. J. Dairy Sci. 77:3022-3033.

Baile, C. A., and C. L. McLaughlin. 1987. Mechanism controlling feed intake in ruminants: A review. J. Anim. Sci. 64:915-922.

Baldwin, R. L. 1995. Modeling Ruminant Digestion and Metabolism. Chapman \& Hall, New York, NY.

Bauman, D. E. 2000. Regulation of nutrient partitioning during lactation: homeostasis and homeorhesis revisited. Pages $311-328$ in Ruminant Physiology: Digestion, Metabolism, Growth and Reproduction. P. B. Cronjé, ed. CABI Publishing, New York, NY.

Bell, A. W. 1995. Regulation of organic nutrient metabolism during transition from late pregnancy to early lactation. J. Anim. Sci. 73:2804-2819.

Bell, A. W., R. Slepetis, and R. A. Ehrhardt. 1995. Growth and accretion of energy and protein in the gravid uterus during late pregnancy in Holstein cows. J. Dairy Sci. 78:1954-1961.

Bibby, J., and H. Toutenburg. 1977. Prediction and Improved Estimation in Linear Models. John Wiley \& Sons, Berlin, Germany.

Blanc, F., and J. Agabriel. 2008. Modelling the reproductive efficiency in a beef cow herd: Effect of calving date, bull exposure and body condition at calving on the calving-conception interval and calving distribution. J. Agric. Sci. 146:143-161.

Boston, R. C., P. A. Wilkins, and L. O. Tedeschi. 2007. Identifiability and accuracy: Two critical problems associated with the application of models in nutrition and the health sciences. Pages 161-193 in Mathematical Modeling for Nutrition and Health Sciences. M. Hanigan, ed. Roanoke, VA.

Burnham, K. P., and D. R. Anderson. 2002. Model Selection and Multimodel Inference: A Practical Information-Theoretic Approach. 2nd ed. Springer-Verlag, New York, NY.

Buskirk, D. D., R. P. Lemenager, and L. A. Horstman. 1992. Estimation of net energy requirements $\left(\mathrm{NE}_{\mathrm{m}}\right.$ and $\left.\mathrm{NE}_{\Delta}\right)$ of lactating beef cows. J. Anim. Sci. 70:3867-3876.

Canfield, R. W., and W. R. Butler. 1991. Energy balance, first ovulation and the effects of naloxone on $\mathrm{LH}$ secretion in early postpartum dairy cows. J. Anim. Sci. 69:740-746.

Clark, P. W., and L. E. Armentano. 1997. Influence of particle size on the effectiveness of beet pulp fiber. J. Dairy Sci. 80:898-904.

DeVries, T. J., M. A. G. von Keyserlingk, and K. A. Beauchemin. 2003. Short communication: Diurnal feeding pattern of lactating dairy cows. J. Dairy Sci. 86:4079-4082.

Ferrell, C. L., W. N. Garrett, and N. Hinman. 1976. Growth, development and composition of the udder and gravid uterus of beef heifers during pregnancy. J. Anim. Sci. 42:1477-1489.

Forbes, J. M. 1980. A model of the short-term control of feeding in the ruminant: Effects of changing animal or feed characteristics. Appetite 1:21-41.

Forbes, J. M. 1993. Voluntary feed intake. Pages 479-494 in Quantitative Aspects of Ruminant Digestion and Metabolism. J. M. Forbes and J. France, ed. CAB International, Wallingford, UK.

Forbes, J. M. 1995a. Physical limitation of feed intake in ruminants and its interactions with other factors affecting intake. Pages 217 232 in Ruminant Physiology: Digestion, Metabolism, Growth and Reproduction: Proc. 8th Intl. Symp. Rumin. Physiol., Willingen, Hesse, Germany. Ferdinand Enke Verlag, Stuttgart, Germany. 
Forbes, J. M. 1995b. Voluntary Food Intake and Diet Selection in Farm Animals. CABI, Oxford, UK.

Forrester, J. W. 1961. Industrial Dynamics. MIT Press, Cambridge, MA.

Fox, D. G., L. O. Tedeschi, T. P. Tylutki, J. B. Russell, M. E. Van Amburgh, L. E. Chase, A. N. Pell, and T. R. Overton. 2004. The Cornell Net Carbohydrate and Protein System model for evaluating herd nutrition and nutrient excretion. Anim. Feed Sci. Technol. 112:29-78

Gibb, M. J., W. E. Ivings, M. S. Dhanoa, and J. D. Sutton. 1992. Changes in body components of autumn-calving Holstein Friesian cows over the first 29 weeks of lactation. Anim. Prod. 55:339-360.

Hayirli, A., R. R. Grummer, E. V. Nordheim, and P. M. Crumps. 2003. Models for predicting dry matter intake of Holsteins during the prefresh transition period. J. Dairy Sci. 86:1771-1779.

Houghton, P. L., R. P. Lemenager, L. A. Horstman, K. S. Hendrix and G. E. Moss. 1990a. Effects of body composition, pre- and postpartum energy level and early weaning on reproductive performance of beef cows and preweaning calf gain. J. Anim. Sci. 68:1438-1446.

Houghton, P. L., R. P. Lemenager, G. E. Moss, and K. S. Hendrix. 1990b. Prediction of postpartum beef cow body composition using weight to height ratio and visual body condition score. J. Anim. Sci. $68: 1428-1437$.

Illius, A. W., and I. J. Gordon. 1991. Prediction of intake and digestion in ruminants by a model of rumen kinetics integrating animal size and plant characteristics. J. Agric. Sci. 116:145-157.

Ingvartsen, K. L., and B. B. Andersen. 2000. Integration of metabolism and intake regulation: A review focusing on periparturient animals. J. Dairy Sci. 83:1573-1597.

King, T. S., and V. M. Chinchilli. 2001. Robust estimator of the concordance correlation coefficient. J. Biopharm. Stat. 11:83-105.

Kirkland, R. M., T. Yan, R. E. Agnew, and F. J. Gordon. 2002. Efficiency of use of body tissue energy for milk production in lactating dairy cows. Livest. Prod. Sci. 73:131-138.

Komaragiri, M. V. S., and R. A. Erdman. 1997. Factors affecting body tissue mobilization in early lactating dairy cows: 1 . Effect of dietary protein on mobilization of body fat and protein. J. Dairy Sci. 80:929-937.

Kononoff, P. J., H. M. Deobald, E. L. Stewart, A. D. Laycock, and F. L. S. Marquess. 2005. The effect of a leptin single nucleotide polymorphism on quality grade, yield grade, and carcass weight of beef cattle. J. Anim. Sci. 83:927-932

Kononoff, P. J., S. K. Ivan, W. Matzke, R. J. Grant, R. A. Stock, and T. J. Klopfenstein. 2006. Milk production of dairy cows fed wet corn gluten feed during the dry period and lactation. J. Dairy Sci. 89:2608-2617.

Kutner, M. H., C. J. Nachtsheim, J. Neter, and W. Li. 2005. Applied Linear Statistical Models. 5th ed. McGraw-Hill Irwin, New York, NY.

Liao, J. J. Z. 2003. An improved concordance correlation coefficient. Pharm. Stat. 2:253-261.

Lin, L. I.-K. 1989. A concordance correlation coefficient to evaluate reproducibility. Biometrics 45:255-268.

Mao, I. L., K. Sloniewski, and P. M. Jensen. 2004. Changes in body condition score and in its genetic variation during lactation. Livest. Prod. Sci. 89:55-65.

Mbanya, J. N., M. H. Anil, and J. M. Forbes. 1993. The voluntary intake of hay and silage by lactating cows in response to ruminal infusion of acetate or propionate, or both, with or without distension of the rumen by a balloon. Br. J. Nutr. 69:713-720.

McNamara, J. P. 2000. Integrating the effects of genotype and nutrition on utilization of body reserved during lactation of dairy cows. Pages 353-369 in Ruminant Physiology: Digestion, Metabolism, Growth and Reproduction. P. B. Cronjé, ed. CABI Publishing, New York, NY.

McNamara, J. P., and R. L. Baldwin. 2000. Estimation of parameters describing lipid metabolism in lactation: Challenge of existing knowledge described in a model of metabolism. J. Dairy Sci. 83:128-143.
Mertens, D. R. 2005. Rate and extent of digestion. Pages 13-47 in Quantitative Aspects of Ruminant Digestion and Metabolism. J. Dijkstra, J. M. Forbes and J. France, ed. CAB International, Wallingford, UK.

Morrison, D. G., J. C. Spitzer, and J. L. Perkins. 1999. Influence of prepartum body condition score change on reproduction in multiparous beef cows calving in moderate body condition. J. Anim. Sci. $77: 1048-1054$

NRC. 2000. Nutrient Requirements of Beef Cattle. Updated 7th ed National Academy Press, Washington, DC.

NRC. 2001. Nutrient Requirements of Dairy Cattle. 7th ed. National Academy Press, Washington, DC.

Otto, K. L., J. D. Ferguson, D. G. Fox, and C. J. Sniffen. 1991. Relationship between body condition score and composition of ninth to eleventh rib tissue in Holstein dairy cows. J. Dairy Sci. 74:852859.

Petruzzi, H., and A. Danfær. 2004. A dynamic model of feed intake regulation in dairy cows. Model description. J. Anim. Feed Sci. $13: 1-23$.

Petruzzi, H. A. Danfær, and N. Friggens. 2004. A dynamic model of feed intake regulation in dairy cows. Model evaluation. J. Anim. Feed Sci. 13:25-49.

Poppi, D. P., M. Gill, and J. France. 1994. Integration of theories of intake regulation in growing ruminants. J. Theor. Biol. 167:129145.

Prior, R. L., R. A. Scott, D. B. Laster, and D. R. Campion. 1979. Maternal energy status and development of liver and muscle in the bovine fetus. J. Anim. Sci. 48:1538-1545.

Pryce, J. E., M. P. Coffey, and S. Brotherstone. 2000. The genetic relationship between calving interval, body condition score and linear type and management traits in registered Holsteins. J. Dairy Sci. 83:2664-2671

Rattray, P. V., W. N. Garrett, N. Hinman, and N. E. East. 1974 Energy cost of protein and fat deposition in sheep. J. Anim. Sci 38:378-382

Rattray, P. V., and J. P. Joyce. 1976. Utilization of metabolizable energy for fat and protein deposition in sheep. N. Z. J. Agric. Res. 19:299-305.

Reed, B. K., C. W. Hunt, R. G. Sasser, P. A. Momont, L. M. Rode, and J. P. Kastelic. 1997. Effect of forage:concentrate ratio on digestion and reproduction in primiparous beef heifers. J. Anim. Sci. $75: 1708-1714$

Reyes, A. A., R. W. Blake, C. R. Shumway, and J. T. Long. 1981 Multistage optimization model for dairy production. J. Dairy Sci. 64:2003-2016.

Reynolds, C. K., P. C. Aikman, B. Lupoli, D. J. Humphries, and D. E. Beever. 2003. Splanchnic metabolism of dairy cows during the transition from late gestation through early lactation. J. Dairy Sci. 86:1201-1217.

Reynoso-Campos, O., D. G. Fox, R. W. Blake, M. C. Barry, L. O Tedeschi, C. F. Nicholson, H. M. Kaiser, and P. A. Oltenacu. 2004 Predicting nutritional requirements and lactation performance of dual-purpose cows using a dynamic model. Agric. Syst. 80:67-83.

Schwager-Suter, R. C. Stricker, D. Erdin, and N. Künzi. 2001. Net energy efficiencies of Holstein, Jersey, and Holstein-Jersey F1crosses. Anim. Sci. 72:335-342.

Sterman, J. D. 2000. Business Dynamics: Systems Thinking and Modeling for a Complex World. Irwin McGraw-Hill, New York, NY.

Sutton, J. D., M. S. Dhanoa, S. V. Morant, J. France, D. J. Napper, and E. Schuller. 2003. Rates of production of acetate, propionate, and butyrate in the rumen of lactating dairy cows given normal and low-roughage diets. J. Dairy Sci. 86:3620-3633.

Tedeschi, L. O. 2006. Assessment of the adequacy of mathematical models. Agric. Syst. 89:225-247.

Tedeschi, L. O., and R. Boston. 2010. Identifiability and accuracy: A closer look at contemporary contributions and changes in these vital areas of mathematical modelling. Pages 91-99 in Modelling Nutrient Digestion and Utilization in Farm Animals, Paris, France. University of Wageningen Press, Wageningen, the Netherlands. 
Tedeschi, L. O., D. G. Fox, and P. J. Guiroy. 2004. A decision support system to improve individual cattle management. 1. A mechanistic, dynamic model for animal growth. Agric. Syst. 79:171-204.

Tedeschi, L. O., S. Seo, D. G. Fox, and R. Ruiz. 2006. Accounting for energy and protein reserve changes in predicting diet-allowable milk production in cattle. J. Dairy Sci. 89:4795-4807.

Van Soest, P. J. 1994. Nutritional Ecology of the Ruminant. 2nd ed. Comstock Publishing Associates, Ithaca, NY.

Vernon, R. G., and K. L. Houseknecht. 2000. Adipose tissue: Beyond an energy reserve. Pages 171-186 in Ruminant Physiology: Digestion, Metabolism, Growth and Reproduction. P. B. Cronjé, ed. CABI Publishing, New York, NY.
Wallach, D., and B. Goffinet. 1989. Mean squared error of prediction as a criterion for evaluating and comparing system models. Ecol. Modell. 44:299-306.

Weder, C. E., T. DelCurto, T. Svejcar, J. R. Jaeger, and R. K. Bailey. 1999. Influence of supplemental alfalfa quality on the intake, use, and subsequent performance of beef cattle consuming low-quality roughages. J. Anim. Sci. 77:1266-1276.

Williams, C. B., P. A. Oltenacu, and C. J. Sniffen. 1989. Refinements in determining the energy value of body tissue reserves and tissue gains from growth. J. Dairy Sci. 72:264-269.

Wood, P. D. P. 1967. Algebraic model of the lactation curve in cattle. Nature 216:164-165. 